\title{
Performance Base Empirical Analysis of Mutual Fund of Nepal
}

\author{
Tara Prasad Upadhyaya, Sirjana Chhetri \\ Tribhuvan University, Lumbini Banijya Campus, Butwal, Nepal \\ Email: tpug1969@gmail.com, sirjanachhetri01@gmail.com
}

How to cite this paper: Upadhyaya, T. P., \& Chhetri, S. (2019). Performance Base Empirical Analysis of Mutual Fund of Nepal. Journal of Financial Risk Management, 8, 43-54.

https://doi.org/10.4236/jfrm.2019.82004

Received: March 19, 2019

Accepted: June 1, 2019

Published: June 4, 2019

Copyright $\odot 2019$ by author(s) and Scientific Research Publishing Inc. This work is licensed under the Creative Commons Attribution International License (CC BY 4.0).

http://creativecommons.org/licenses/by/4.0/

(c) (i) Open Access

\begin{abstract}
The paper analyzes the returns earned by the sample mutual funds benchmarking with market return. It also assesses whether they are taking advantages of diversification, market timing and selectivity of securities to their investors. Secondary data of eight sample mutual funds' have been used from 2015 to 2018 published by Nepal Stock Exchange and respective fund manager. Risk adjusted performance measures Jensen alpha, Treynor ratio and Sharpe ratio have been used to analyze return in terms of risk and Co-efficient of Determination $\left(\mathrm{R}^{2}\right)$, Quadratic Regression of Treynor and Mazuy and Famade composition model are employed to assess diversification, market timing and selectivity ability of fund manager. The result explores that funds that are operated from 36 months over-perform benchmark market index and those funds operated for 16 months are suffering from very low return. Further evidence shows that low amount of diversification, moderate level of selectivity and no significant relationship between timing skill and return of funds.
\end{abstract}

\section{Keywords}

Mutual Fund, Risk, Benchmark, Return

\section{Introduction}

A Mutual Fund is an investment vehicle that pools funds from various investors and invests the funds in stocks, bonds, short-term money-market instruments, other securities or assets or some combination of these investments. The primary goal behind investment in mutual fund is to earn good return with comparatively low risk.

The popularity of mutual fund investment among private investors has grown dramatically all over the world during last 40 years. Therefore, mutual fund per- 
formance has always been one of the most researched areas of finances. At the end of 2016, mutual fund assets worldwide were $\$ 40.4$ trillion. Total net assets in worldwide regulated funds hit $\$ 49.3$ trillion at year-end 2017, it increased to $\$ 50.01$ trillion at the end of the first quarter of 2018 (Investment Company Institute, 2018).

The history of mutual fund in Nepal started with the establishment of "NCM Mutual Fund 1993" by Nepal Industrial Development Corporation (NIDC) Capital Market in 1993. The term of the NCM Mutual Fund 1993 was completed in 2001 and it was converted into close-end fund in the name of "NCM Mutual Fund, 2002" in 2002 (Thapa \& Rana, 2011).

Till June, 2018, there are all together 13 mutual scheme traded on Nepal Stock Exchange with total paid up capital Rs.21,705.2 million whereas Nepal Stock Exchange occupy Rs.367,365.5969 million capital. Mutual fund are occupy only $5.91 \%, 5.81 \%$ and $2.16 \%$ market share of NEPSE in the year 2018-19, 2017-18 and 2016-17 respectively. At 14 may 2018, total turnover of NEPSE is Rs.12,779.19 million in amount and turnover of mutual fund is Rs.20.76 million that is 0.1625\% (Nepal Stock Exchange Exchange, 2018).

Very few research has been completed regarding the mutual fund performance in Nepal. The overall performance evaluation of Nepalese mutual fund is the main aim of this study. The specific objectives is to measure the return earned by sample mutual funds benchmarking with market return in terms of different risk and to assess the mutual fund schemes offering the advantages of diversification, market timing and selectivity of securities to their investors.

The performance of mutual fund in terms risk adjusted return, diversification, market timing and selectivity ability are analyzed by using diverse technical measurement methods. The popular measures introduced and tested by Jenson (1968). Treynor (1965) and Sharpe (1966), are developed on the assumptions of 'The Capital Asset Pricing Model' (CAPM) propounded by Sharpe, Lintner and others has been used to analyze the performance of mutual fund. This paper deals with the performance evaluation of 8 mutual funds in terms risk adjusted return, diversification, market timing and selectivity ability and it has been structured as Section 1: Introduction, Section 2: Review of literature, and Section 3: Methodology and Data Analysis.

\section{Review of Literature}

Numerous theoretical and empirical researches have been conducted on the performance evaluation of mutual fund both in the context of developed and developing countries around the world. This section presents a brief review.

Treynor \& Mazuy (1966)'s study found that none of the investment managers of the 57 funds (1953-1962) outguess the market and that these managers should not be held responsible for failing to anticipate changes in market direction.

Sharpe (1966) evaluate performance of mutual funds using concept from modern portfolio theory. He has developed a composite measure that considers 
return and risk. He evaluated the performance of 34 open-end mutual funds during the period 1944-1963. He concluded that the average mutual fund performance was distinctly inferior to an investment in the DJIA (Dow Jones Industrial Average). It was also revealed that good performance was associated with low expense ratio and only low relationship was discovered between fund size and performance.

Jensen (1969) developed portfolio evaluation model including risk aspects explicitly by utilizing and extending theoretical results by Sharpe (1964) and Lintner (1965) on the pricing of capital assets under uncertainty. The result convey that measure of portfolio performance (which measures only a manager's ability to forecast security prices) is defined as the difference between the actual returns on a portfolio in any particular holding period and the expected returns on that portfolio conditional on the riskless rate, its level of systematic risk, and the actual returns on the market portfolio. Criteria for judging a portfolio's performance to be neutral, superior, or inferior are established.

Fama (1972) introduced a model for evaluating investment performance of managed portfolios. He suggested that the overall performance of managed portfolios could be broken down into several components. He argued that the observed return of a fund could be, due to the ability of fund managers, to pick up the best securities at a given level of risk (their selectivity ability). Some portion of this return could also arise due to the prediction of general market price movements (their market timing ability).

Henriksson (1984), by using both the parametric and non-parametric tests for the evaluation of forecasting ability presented by Henriksson and Merton, the market-timing ability of 116 open-end mutual funds is evaluated for the period 1968-80. He found little evidence of market timing ability of manager.

Grinblatt \& Titman (1989) employ the 1975-84 quarterly holdings of a sample of mutual funds to construct an estimate of their gross returns. They use sample, which is not subject to bias and sample is used to test for the existence of abnormal performance. The tests indicate that the risk-adjusted gross returns of some funds were significantly positive.

Blake \& Timmermann (1998), they obtained some new patterns in performance related to the funds' distance from their inception and termination dates: underperformance intensifies as the fund termination date while, in contrast, there is some evidence that funds (weakly) outperform during their first year of existence. These evidence supported by large sample containing the complete return histories of $2300 \mathrm{UK}$ opened mutual funds over a 23 -year period to measure fund performance.

Galagedera, Roshdi, \& Fuku (2018) suggested that comprehensive performance measurement and fund management of mutual fund process can be conceptualized into three level: to assess overall performance, a network data envelopment analysis model is used, to operate under two different environmental conditional levels of risk and other levels of risk exposure intermediate measure is used. Finally they proposed new index to assess linkage performance is dem- 
onstrated empirically to improve discriminatory power of performance.

Jaydev (1996) evaluates the performance of two growth oriented mutual funds (Mastergain and Magnum Express) on the basis of monthly returns compared to benchmark returns. It is found that, Mastergain has performed better. Biplob (2017) evaluates the performance of 15 close-ends Bangladeshi mutual funds traded in DSE (Dhaka stock exchange) by using Jensen alpha, Treynor ratio, Sharpe ratio. He found that 12 out of 15 funds got superior return compared to benchmark index return. Further he concluded that 9 out of 15 funds are well diversified and have reduced its unique risk, statistically significant timing skill but moderate level of selectivity in mutual fund market of Bangladesh.

Bajracharya (2016) studied seven mutual funds listed in the Nepal stock exchange trade (NEPSE), and concluded that most of the mutual funds have performed better according to Jenson and Treynor measures but not up to the benchmark on the basis of Sharpe ratio and few mutual funds are well diversified and have reduced its unique risk.

\section{1) Average Return}

The performance of mutual fund can be analyzed with the help of produced average return based on NAV by the mutual over the period (Sharpe, Alexander, \& Bailey, 2001) of time. Generally, portfolio performance is evaluated by calculating return which also incorporate dividends and capital gains (Figure 1).

\section{2) Risk}

The risk is calculated on the basis of month-end NAV. The following measures of risks associated with portfolio: Standard Deviation $(\sigma)$, Beta $(\beta)$, Unsystematic Risk $(\sigma \mathrm{Ep})$ are used for evaluation of mutual fund.

\section{3) Benchmark}

A benchmark is a standard against which the performance of a security, mutual fund or investment manager can be measured. Generally, broad market and market-segment stock and bond indices are used for this purpose. Comparison of risk return of other companies can be compared to evaluate performance of the company.

\section{4) Reward to Variability}

It was developed by Sharpe (1966). Sharpe devised an index of portfolio performance measure, referred to as reward o variability ratio. The Sharpe ratio provides the reward to volatility trade-off. It is the ratio of the fund portfolio's average excess return divided by the standard deviation of the return.

\section{5) Reward to Volatility}

Treynor (1965) was the first researcher developing a composite measure of portfolio performance which is called Treynor ratio. Treynor conceived an index of portfolio performance called as reward to volatility ratio based on systematic risk. It is denoted by TP is the excess return over the risk free rate per unit of systematic risk, in other words it risk premium per unit of systematic risk.

\section{6) Selectivity}

Fama and Jensen measures are used to measure the selectivity skills of manager. Jensen (1968) explained, A portfolio manager's predictive ability that is, his 


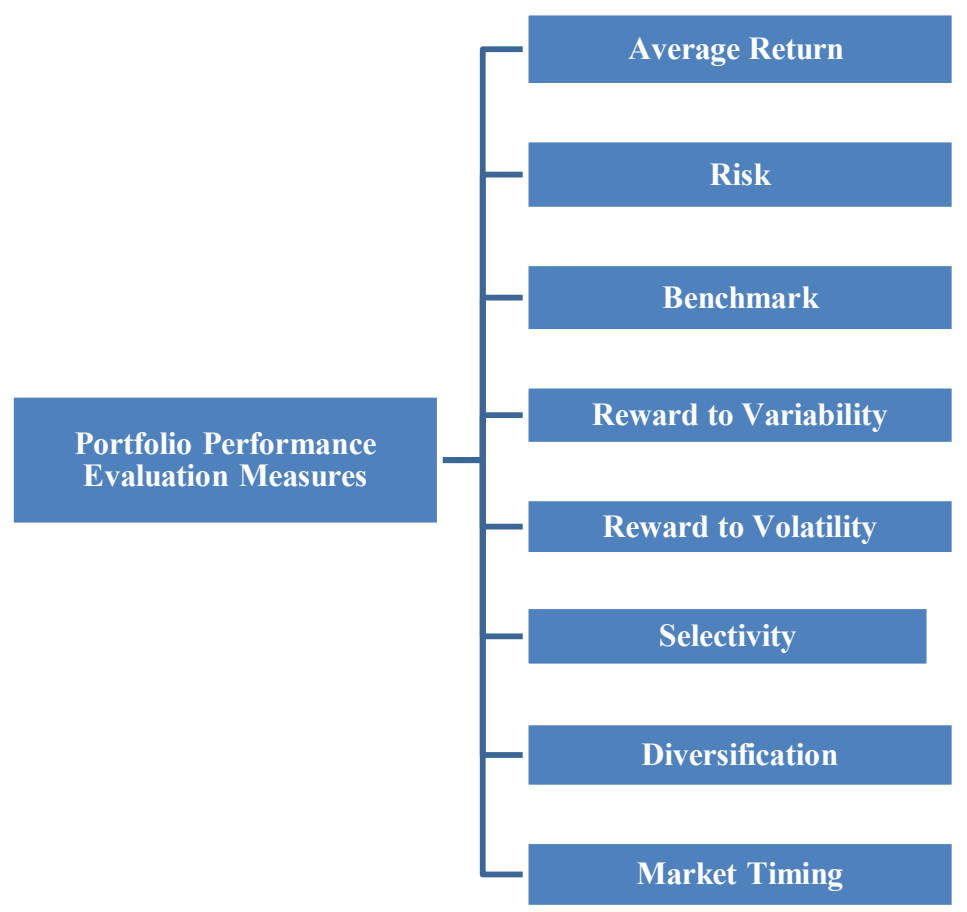

Figure 1. Theoretical framework. Source: Sharpe, Alexander, \& Bailey (2001).

ability to earn returns through the successful forecast of security prices. Similarly, Fama said that while observed return of a fund could be due to the ability of fund managers to pick up best securities at a given level of risk (selectivity). Selectivity can be further decomposed into net selectivity and diversification.

\section{7) Diversification}

One of the important advantages of mutual funds is that a small investor can also enjoy benefits of diversification of portfolio. Further, well diversified portfolio reduces the risk of the portfolio. Diversification can be measured with the help of coefficient of determination $\left(\mathrm{R}^{2}\right)$.

\section{8) Market Timing}

Treynor and Mazuy (1966), developed model to evaluate market-timing performance. Mutual fund managers may hold a higher proportion of the market portfolio if they are qualified to predict future market conditions and envisage the stock market as a bull market. On the other hand, mutual fund managers may hold a lower proportion of the market portfolio if they expect the market to underperform in the future.

\section{Methodology and Data Analysis}

\section{Research Design}

The descriptive research design includes the model: Jensen Measure, Sharpe Ratio, Trenyor Ratio, FamaMeaure, Trenyor and Mazuy Quadratic equation based Capital Assets Pricing Model for analysis of performance, market timing and selectivity ability of mutual funds. The secondary data is collected from monthly and annual report of Nepal Stock Exchange, published Net Assets Val- 
ue of sample mutual fund on respective fund manager, annual report of mutual fund consists income statement and balance sheet, government securities and open market operation statistics published on Nepal Rastra Bank. Out of 13 mutual funds only 8 mutual fund are selected and remaining 5 mutual fund are excluded from the study because they are recently launched in market.

\section{Tools used for Data Analysis}

The popular measures introduced and tested by Jenson (1968). Treynor (1965) and Sharpe (1966), Fama (1972), Treynor and Mazuy (1966) are based on the assumptions of "The Capital Asset Pricing Model" (CAPM) propounded by Sharpe, Lintner and others. The CAPM specifies that in equilibrium the return and risk are in linear relationship called as Security Market Line (SML).

$$
R p=R f+\beta(R m-R f)
$$

where $R p=$ expected return on security portfolio,

$$
R f=\text { Risk Free Return, }
$$

$R m=$ Expected market return,

$\beta=$ systematic risk of portfolio.

For a well-diversified portfolio, above relationship can be specified in terms of the total risk ( $\sigma$ ) of portfolio return, called as Capital Market Line (CML).

$$
R p=R f+\frac{\sigma p(R m-R f)}{\sigma m}
$$

where, $\sigma m$ is the total risk of market index

\section{1) Jensen Alpha}

Michael Jensen (1968) has introduced a portfolio performance measure called Jensen alpha also known as Jensen ratio, defines measure of portfolio performance as the difference between the actual return on a portfolio and the expected returns in any particular holding period on that portfolio conditional on the risk free rate and systematic risk. The positive alpha indicates selection skills of the manager of fund.

$$
a p=A R p-E A R p
$$

where,

$E A R p=$ Equilibrium Average Return $=A R f+\beta p(A r m-A R f)$,

$A p$ is the Jensen Alpha,

$A R p$ is the average portfolio return,

$A R m$ is the average market return,

$A R f$ is the average risk free rate of return,

$B p$ is the systematic risk of portfolio.

\section{2) Treynor Technique}

Treynor ratio is the first risk-adjusted performance measure of mutual funds that was put forward by Treynor in 1965. It is calculated as the ratio of the excess return of the mutual fund divided by its beta (systematic risk) and is defined as:

$$
T_{p}=\frac{A R p-A R f}{\beta p}
$$




$$
T m=\frac{A R m-A R f}{\beta m}
$$

where, $T p$ is Treynor ratio of portfolio,

$T m$ is Treynor ratio of market,

$\beta m$ is systematic risk of market.

Here, excess returns of market over risk free return (ARm - ARf) are the benchmark. Greater value of the portfolio over the market indicates a superior performance of the fund.

\section{3) Sharpe Technique}

The Sharp ratio uses standard deviation to measure total risk of a portfolio rather than to consider only the systematic risk summarized by beta factor. This ratio basically indicates risk premium return earned per unit of total risk. Sharpe introduced the following reward to variability ratio (known as sharp ratio) as follows:

$$
\begin{aligned}
& S p=\frac{A R p-A R f}{\sigma p} \\
& S m=\frac{A R m-A R f}{\sigma m}
\end{aligned}
$$

where, $S p$ is Sharpe ratio of portfolio,

$S m$ is Sharpe ratio of market,

$\sigma p$ is risk of portfolio return,

$\sigma m$ is total risk of market index.

\section{4) Treynor\&Mazuy Regression Analysis}

Treynor and Mazuy (1966) developed the following model to evaluate market-timing performance

$$
R p-R f=a+b(R m-R f)+c(R m-R f)^{2}+E p
$$

where " $a$ " is the timing-adjusted alpha, which represents the timing-adjusted selective ability of mutual fund managers. The quadratic term in equation is the market timing factor and the coefficient of the market timing factor, " $b$ " represents mutual fund managers' market timing ability. If “ $b$ " is positive, mutual fund managers have superior market timing ability i.e., the investment portfolios of mutual funds are adjusted actively to well-anticipated changes in market conditions. A negative implies that mutual fund managers do not exhibit market timing ability.

\section{5) Fama Measures}

Fama measures breaks down the observed return into four components:

1) Risk free return $R f$

2) Compensation for systematic risk $\beta(R m-R f)$

3) Compensation for inadequate diversification $(R m-R f)\{(\sigma p / \sigma m)-\beta\}$

4) Net superior returns due to selectivity $(R p-R f)-\{(\sigma p / \sigma m)(R m-R f)\}$

The second and third measures indicate the impact of diversification and market risk. By altering systematic and unique risk a portfolio can be reshuffled 
to get the desired return. Fama performance measures denoted by Fp are defined as:

$$
\begin{aligned}
F p & =\text { Portfolio Return }- \text { Risk free return }- \text { Returns due to all risks } \\
& =(R p-R f)-\{(\sigma p / \sigma m)(R m-R f)\}
\end{aligned}
$$

A positive value for Fp indicates that the fund earned returns higher than expected returns and lies above CML and a negative value indicates that the fund earned return less than expected returns and lies below CML.

\section{6) Diversification}

Diversification can be measured with the help of coefficient of determination $\left(R^{2}\right)$. This can be obtained by regressing the portfolio's additional return $(R p-$ $R f)$ against the market additional returns $(R m-R f)$. A high value indicates greater diversification of fund and vice-versa.

The sample in this study consist of 8 mutual fund traded in Nepal Stock Exchange which we group them into two group to analyze separately. First group consist four mutual fund which are operating from 36 month and more, NAV is taken from May 2015 to May 2018. Group B consist also four mutual fund which are operating from are 16 month and more. Furthermore, dividend also has been adjusted in the return of mutual fund. In this context only four mutual fund of Group A has been distributed dividend to its shareholders two times during the period of 36 months, i.e adjusted in return after 3 month of declaration date. But in Group B no any mutual fund distributed dividend. Further, interest rate of 182 days Treasury bills published by Nepal Rastra Bank (2018) on 14 May 2018 has been taken as risk free rate of return.

Table 1 indicates that the mutual fund from group A (based on dividend adjusted return) all fund generate positive Jensen alpha. In Group B two funds (NEF and NIBLPF) show negative alpha, on overall basis fund industry alpha is good. In Group A, out of the four mutual funds under consideration it has been found that LVF1 with alpha of 0.6621 . Similarly, GIMESL got the highest Jensen alpha 0.6081 from Group B. Precisely, finding overall positive alpha from this study indicates that funds are able to generate higher return than equilibrium return using CAPM.

Similarly, result shows that all the funds except LVF1 have experienced higher than market return in case of Treynor ratio also called reward to volatility ratio i.e., return per unit of systematic risk $(\beta)$ in Group A fund but in market NMBSF 1 performs better than others. All fund except NEF are earning negative return as reward to volatility from Group B whereas in market all are performing negative return.

The result unveils that from group A all funds have generated higher Sharpe ratio also called reward to variability ratio i.e., return per unit of total risk (б) than that of market return. NMBSF1 got the highest excess return over risk-free return for taking per unit of total risk i.e. 0.1302. But in group all funds except $\mathrm{NEF}$ in market have negative return against for taking per unit of total risk. In 
Table 1. Risk adjusted performance measure.

\begin{tabular}{ccccccccc}
\hline & \multicolumn{3}{c}{ Group A (Period 36 months) } & \multicolumn{4}{c}{ Group } & \multicolumn{3}{c}{ (Period 16 months) } \\
\hline $\begin{array}{c}\text { Risk Adjusted Measures/ } \\
\text { Mutual Fund }\end{array}$ & $\begin{array}{c}\text { Siddhartha Equity } \\
\text { Oriented Scheme }\end{array}$ & $\begin{array}{c}\text { NMB Sulav } \\
\text { Investment } \\
\text { Fund 1 }\end{array}$ & $\begin{array}{c}\text { NIBL } \\
\text { Samriddhi } \\
\text { Fund 1 }\end{array}$ & $\begin{array}{c}\text { Laxmi } \\
\text { Value } \\
\text { Fund 1 }\end{array}$ & $\begin{array}{c}\text { Global IME } \\
\text { Samunnat } \\
\text { Scheme 1 }\end{array}$ & $\begin{array}{c}\text { NMB } \\
\text { Hybrid } \\
\text { Fund L1 }\end{array}$ & $\begin{array}{c}\text { Nabil } \\
\text { Equity } \\
\text { Fund }\end{array}$ & $\begin{array}{c}\text { NIBL } \\
\text { Pragati } \\
\text { Fund 1 }\end{array}$ \\
\hline Symbol & SEOS & NMBSF1 & NIBLS 1 & LVF1 & GIMESL & NMBHF1 & NEF & NIBLPF \\
\hline $\begin{array}{c}\text { Jensen's alpha }(\boldsymbol{\alpha}) \\
\text { Treynor Ratio }(T p)\end{array}$ & 0.2839 & 0.6242 & 0.5536 & 0.6621 & 0.6081 & 0.0012 & -0.8941 & -0.9645 \\
$\begin{array}{c}\text { Market return Treynor } \\
\text { ratio }(T m)\end{array}$ & 1.5369 & 2.0983 & 5.8659 & -2.5311 & -0.2926 & -0.7419 & 6.8755 & -2.2863 \\
$\begin{array}{c}\text { Sharpe ratio }(S p) \\
\text { Market return Sharpe } \\
\text { ratio }(S m)\end{array}$ & 0.3616 & 1.2114 & 0.7858 & 0.2913 & -1.2173 & -0.7467 & -1.2573 & -0.4626 \\
$\quad$ & 0.0520 & 0.1302 & 0.0898 & 0.0833 & -0.0324 & -0.1409 & -0.3010 & -0.2927 \\
\hline
\end{tabular}

case of market NIBLSF1 and NEF are performing better than other from both Group.

Table 2 discloses that based on dividend adjusted return all the funds from Group A have positive return. Out of four three fund earning greater than market return, they are: SEOS, NMBSF1, LVF1. On the other hand, some mutual funds have lower total risk than market. In addition mutual funds return are less sensitive than market since all fund have Beta less than 1. In Group B, all mutual funds are performing lower than risk free rate of return, GIMESL, NIBLPF have greater risk than market but other have lower risk than market. Beta is also lower than 1 it refers lower sensitivity of stock.

Table 3 depict that with low $\mathrm{R}^{2}$ value of mutual fund represented the less diversification of the portfolio and the high $\mathrm{R}^{2}$ value indicates the well diversified portfolio. Most of the funds indicate the low $\mathrm{R}^{2}$ that the portfolio is less diversified its unique risk and is high unsystematic risk is low but the total risk is very high.

On the other, NMBSF1 and NMBHF1 from Group A and B respectively have higher $\mathrm{R}^{2}$ indicates low total risk, systematic risk and unsystematic risk because of well diversified portfolio. Managers of other fund are taking some level of diversifiable risk (unsystematic risk, $\sigma \mathrm{Ep}$ ).

Table 4 reveals that Group A and Group B has positive $c$-coefficient but none of them has been found statistically significant at any level of significance. Moreover using Treynor and Mauzy Quadratic equation, a (alpha) which represent selectivity of fund. Out eight five funds have positive selectivity but none of the fund is statistically significant at any level of significance.

Table 5 presents breaks up of Portfolio returns with the help of Fama's decomposition measure. The result unfolds all funds from group A have earned superior monthly return because of the security selection ability on the part of the fund managers. And all funds from Group B earning negative return, it means that fund managers have taken diversifiable risk that has not been compensated by the extra returns. 
Table 2. Descriptive summary statistics of mutual funds and market index.

\begin{tabular}{lcccccccc}
\hline & \multicolumn{3}{c}{ Group A (Period 36 months) } & \multicolumn{4}{c}{ Group (Period 16 months) } \\
\hline \multicolumn{1}{c}{ Symbol } & SEOS & NMBSF1 & NIBLSF1 & LVF1 & GIMESL & NMBHF1 & NEF & NIBLPF \\
\hline Average monthly return $\left(A R_{P}\right)$ & 0.8049 & 1.2341 & 1.0720 & 1.0274 & 0.2412 & 0.2501 & -0.3223 & -0.7930 \\
Average monthly market return $\left(\boldsymbol{A} \boldsymbol{R}_{M}\right)$ & 0.7951 & 0.8957 & 1.2194 & 0.7248 & -0.7837 & -0.3131 & -0.8237 & -0.029 \\
Average risk free rate of return $\left(\boldsymbol{A R _ { F }}\right)$ & 0.4336 & 0.4336 & 0.4336 & 0.4336 & 0.4336 & 0.4336 & 0.4336 & 0.4336 \\
Portfolio risk $(\boldsymbol{\sigma})$ & 7.1381 & 6.1489 & 7.1190 & 7.1303 & 5.9327 & 1.3022 & 2.5114 & 4.1912 \\
Risk of market return $(\boldsymbol{\sigma m})$ & 7.6635 & 7.4185 & 10.267 & 9.9628 & 2.0712 & 2.8774 & 2.5515 & 3.3870 \\
Volatility $(\boldsymbol{\beta})$ (Digit) & 0.2416 & 0.3815 & 0.1090 & -0.2346 & 0.6576 & 0.2474 & -0.1099 & 0.5667 \\
\hline
\end{tabular}

Table 3. Risk and diversification.

\begin{tabular}{ccccccccc}
\hline & \multicolumn{3}{c}{ Group A (Period 36 months) } & \multicolumn{5}{c}{ Group (Period 16 months) } \\
\hline Symbol & SEOS & NMBSF1 & NIBLSF1 & LVF1 & GIMESL & NMBHF1 & NEF & NIBLPF \\
\hline Total risk $(\sigma p)$ & 7.1381 & 6.1489 & 7.1190 & 7.1303 & 5.9327 & 1.3022 & 2.5114 & 4.1912 \\
Systematic Risk $(\beta p)$ & 0.2416 & 0.3815 & 0.1090 & -0.2346 & 0.6576 & 0.2474 & -0.1099 & 0.5667 \\
Unsystematic risk $(E \sigma p)$ & 0.0689 & 0.0549 & 0.0703 & 0.0706 & 0.0577 & 0.0114 & 0.0254 & 0.0322 \\
Diversification $\left(R^{2}\right)$ & 0.0673 & 0.2061 & 0.0247 & 0.0989 & 0.0527 & 0.2801 & 0.0120 & 0.2619 \\
\hline
\end{tabular}

Table 4. Treynor and mauzy quadratic equation.

\begin{tabular}{ccccccccc}
\hline Mutual Fund & \multicolumn{3}{c}{ Group A (Period 36 months) } & \multicolumn{4}{c}{ Group (Period 16 months) } \\
\hline Symbol & SEOS & NMBSF1 & NIBLSF1 & LVF1 & GIMESL & NMBHF1 & NEF & NIBLPF \\
\hline a & 0.6244 & 1.0796 & 0.1930 & 1.7047 & 0.2842 & -0.0396 & -0.8677 & -2.383 \\
P value of a & 0.6383 & 0.3254 & 0.8812 & 0.2004 & 0.8665 & 0.9197 & 0.3581 & 0.0823 \\
b & 0.2716 & 0.4613 & 0.0931 & -0.0435 & 2.4481 & 0.2485 & -0.1254 & 0.3942 \\
c & -0.0059 & -0.0092 & 0.0035 & -0.0111 & 0.4337 & 0.0044 & -0.0057 & 0.0449 \\
P value of c & 0.5663 & 0.4131 & 0.4343 & 0.0550 & 0.0838 & 0.8376 & 0.9476 & 0.4264 \\
\hline
\end{tabular}

Table 5. Break up of portfolio returns.

\begin{tabular}{lcccccccc}
\hline \multicolumn{1}{c}{ Mutual Fund } & \multicolumn{3}{c}{ Group A (Period 36 months) } & \multicolumn{3}{c}{ Group (Period 16 months) } \\
\hline \multicolumn{1}{c}{ Symbol } & SEOS & NMBSF1 & NIBLSF1 & LVF1 & GIMESL & NMBHF1 & NEF & NIBLPF \\
\hline 1) Risk free return & 0.4336 & 0.4336 & 0.4336 & 0.4336 & 0.4336 & 0.4336 & 0.4336 & 0.4336 \\
2) Impact of systematic risk & 0.0874 & 0.1763 & 0.0856 & -0.0683 & -0.8005 & -0.1847 & 0.1382 & -0.2621 \\
3) Impact of imperfect diversification & 0.2494 & 0.2067 & 0.4592 & 0.2767 & -2.6862 & -0.1532 & -1.3757 & -0.3103 \\
4) Return for taking risk (2+3) & 0.3368 & 0.383 & 0.5448 & 0.2084 & -3.4867 & -0.3379 & -1.2375 & -0.5724 \\
5) Net superior return (2+3) & 0.0345 & 0.4174 & 0.0944 & 0.3854 & -3.6792 & -0.5215 & -1.9934 & -1.7990 \\
6) Portfolio return (1+4+5) & 0.8049 & 1.234 & 1.0728 & 1.0274 & 0.2412 & 0.2500 & -0.3223 & -0.7930 \\
\hline
\end{tabular}


Table 6. Return and risk on portfolios (figure in \%).

\begin{tabular}{ccccc}
\hline & \multicolumn{2}{c}{ Group A (Period 36 months) } & \multicolumn{2}{c}{ Group (Period 16 months) } \\
\cline { 2 - 5 } & $\begin{array}{c}\text { Performance of Mutual } \\
\text { Fund (Monthly NAV) }\end{array}$ & $\begin{array}{c}\text { Performance of Mutual Fund } \\
\text { (Market Return) }\end{array}$ & $\begin{array}{c}\text { Performance of Mutual } \\
\text { Fund (Monthly NAV) }\end{array}$ & $\begin{array}{c}\text { Performance of } \\
\text { Mutual Fund } \\
\text { (Market Return) }\end{array}$ \\
\hline Average Return & 1.0346 & 0.9088 & -0.1560 & -0.4874 \\
Standard Deviation & 0.1533 & 0.1894 & 0.4348 & 0.8237 \\
Minimum Return & 0.8049 & 0.7248 & -0.7930 & -0.0290 \\
Maximum Return & 1.2341 & 1.2194 & 0.2501 & 0.3322 \\
Median Return & 1.0497 & 0.8454 & -0.0406 & -0.5484 \\
\hline
\end{tabular}

Table 6 reveals that in Group A from May 2015 to May 2018 on an average mutual fund earned return of $1.0346 \%$ monthly with standard deviation of 0.1533 monthly based on monthly NAV. Whereas average monthly return of market in this period was 0.9088 with the standard deviation 0.1894 . Which indicates mutual funds' performance was better than market index. In Group B from February 2017 to May 2018 on an average mutual fund monthly earned return of $-0.1560 \%$ with standard deviation of 0.4348 based on monthly NAV. Whereas average monthly return of market in this period was -0.4874 with the standard deviation of 0.8237 which indicates mutual funds' performance and market performance both are not good.

\section{Conclusion}

The results pertaining to the selectivity skills of fund managers have indicated that all of group A possess positive net stock selection ability of portfolio managers have found positive for majority of schemes but Group B mutual fund have negative net selectivity ability. So it can be concluded that over research period mutual funds are over-perform benchmark market index and it depicts low amount of diversification, moderate level of selectivity and no significant relationship between timing skill and return of funds. Mutual Funds have contributed significantly to shaping economy. To accelerate economic growth and enhance the financial capabilities of small household, it is the better solution for investment issue since small amount can be employed through good selection and timing strategy.

\section{Conflicts of Interest}

The authors declare no conflicts of interest regarding the publication of this paper.

\section{References}

Bajracharya, R. B. (2016). Mutual Fund Performance in Nepalese Mutual Fund Units: An Analysis of Monthly Returns. Journal of Advanced Academic Research, 3, 92-100. https://doi.org/10.3126/jaar.v3i2.16758 
Biplob, M. N. (2017). Performance Evaluation of Bangladeshi Mutual Fund: An Analysis of Monthly Return Based on Net Asset Value. International Journal of Economics and Management Sciences, 6, 428. https://doi.org/10.4172/2162-6359.1000428

Blake, D., \& Timmermann, A. (1998). Mutual Fund Performance: Evidence from the UK. Review of Finance, 2, 57-77. https://doi.org/10.1023/A:1009729630606

Fama, F. E. (1972). Component If Investment Performance. Journal of Finance, 27, 551-567. https://doi.org/10.1111/j.1540-6261.1972.tb00984.x

Galagedera, D., Roshdi, I., \& Fuku, H. (2018). A New Network DEA Model for Mutual Fund Performance Appraisal: An Application to U.S. Equity Mutual Funds. Omega, 77, 168-179. https://doi.org/10.1016/j.omega.2017.06.006

Grinblatt, M., \& Titman, S. (1989). Mutual Fund Performance: An Analysis of Quarterly Portfolio Holdings. The Journal of Business, 62, 393-416. https://doi.org/10.1086/296468

Henriksson, R. D. (1984). Market Timing and Mutual Fund Performance: An Empirical Investigation. The Journal of Business, 57, 73-96. https://doi.org/10.1086/296225

Investment Company Institute (2018). Research \& Statistics. https://www.ici.org/research/investors

Jensen, M. C. (1969). Risk, the Pricing of Capital Assets, and the Evaluation of Investment Portfolios. Journal of Business, 42, 167-247. https://doi.org/10.1086/295182

Nepal Rastra Bank (2018). Public Debt. https://nrb.org.np/pdm/pdmindex.php

Nepal Stock Exchange Exchange (2018). Reports. http://www.nepalstock.com/reports-by-category

Sharpe, W. F. (1966). Mutual Fund Performance. The Journal of Business, 39, 119-138. https://doi.org/10.1086/294846 http://www.jstor.org/stable/2351741

Sharpe, W. F., Alexander, G. J., \& Bailey, J. V. (2001). Investment. New Delhi: Prentice Hall of India.

Thapa, K., \& Rana, S. B. (2011). Investment Management (3rd ed.). Kathmandu: Asmita Books Publishers \& Distributors Private Ltd.

Treynor, J. L., \& Mazuy, K. (1966). Can Mutual Funds Outguess the Market? Harvard Business Review, 4, 131-136. 